\title{
New approaches in antimalarial drug discovery and development - A Review
}

\author{
Anna Caroline C Aguiar ${ }^{1,2}$, Eliana MM da Rocha ${ }^{1,3}$, \\ Nicolli B de Souza', Tanos CC França ${ }^{4}$, Antoniana U Krettlii,2/+
}

\begin{abstract}
${ }^{1}$ Centro de Pesquisas René Rachou-Fiocruz, Belo Horizonte, MG, Brasil ${ }^{2}$ Programa de Pós-Graduação em Medicina Molecular, Universidade Federal de Minas Gerais, Belo Horizonte, MG, Brasil ${ }^{3}$ Universidade Federal de São João del Rei, Divinópolis, MG, Brasil

${ }^{4}$ Laboratório de Modelagem Aplicada à Defesa Química e Biológica, Instituto Militar de Engenharia, Rio de Janeiro, RJ, Brasil
\end{abstract}

Malaria remains a major world health problem following the emergence and spread of Plasmodium falciparum that is resistant to the majority of antimalarial drugs. This problem has since been aggravated by a decreased sensitivity of Plasmodium vivax to chloroquine. This review discusses strategies for evaluating the antimalarial activity of new compounds in vitro and in animal models ranging from conventional tests to the latest high-throughput screening technologies. Antimalarial discovery approaches include the following: the discovery of antimalarials from natural sources, chemical modifications of existing antimalarials, the development of hybrid compounds, testing of commercially available drugs that have been approved for human use for other diseases and molecular modelling using virtual screening technology and docking. Using these approaches, thousands of new drugs with known molecular specificity and active against $\mathrm{P}$. falciparum have been selected. The inhibition of haemozoin formation in vitro, an indirect test that does not require $\mathrm{P}$. falciparum cultures, has been described and this test is believed to improve antimalarial drug discovery. Clinical trials conducted with new funds from international agencies and the participation of several industries committed to the eradication of malaria should accelerate the discovery of drugs that are as effective as artemisinin derivatives, thus providing new hope for the control of malaria.

Key words: human malaria - Plasmodium falciparum - antimalarials drug screening - chloroquine - artemisinin - drug resistance

According to the World Health Organization (WHO), malaria remains a major health problem and affects more than 225 million individuals, causing approximately 700 thousand deaths each year. Plasmodium falciparum is the most common causative agent (WHO 2011). However, Plasmodium vivax malaria, which was previously considered benign, also causes life-threatening symptoms. $P$. vivax is the most prevalent species in Latin America, South-East Asia, the Eastern Mediterranean and the Western Pacific (WHO 2011). Plasmodium malariae and Plasmodium ovale are less prevalent and cause less severe disease in humans, whereas Plasmodium knowlesi, a parasite of Old World monkeys, causes human disease in Southeast Asia (Cox-Singh \& Singh 2008). In addition, drug resistance has been reported in P. vivax malaria (Price et al. 2009).

Sporozoites, injected by Anopheles mosquitoes as they bite into the skin of mammalian hosts, rapidly enter the blood circulation to reach liver hepatocytes, where they mature in an entirely asymptomatic phase that lasts

Financial support: CNPq (MCT/CNPq/CT-Saúde/MS/SCTIE/ DECIT), FAPEMIG, FIOCRUZ (PDTIS, PAPES V) AUK, ACCA, NBS and WJC have fellowships from CNPq. ACCA and EMM da R contributed equally to this work.

+Corresponding author: akrettli@cpqrr.fiocruz.br

Received 1 July 2012

Accepted 16 August 2012 for approximately two weeks. Sporozoites of $P$. vivax and $P$. ovale remain dormant (hypnozoites) in the human hepatocyte, where they mature months to years later. These forms cause late malaria relapses under conditions that are not well understood and are related to host stress and low primaquine (PQ) doses (Townell et al. 2012); such relapses require new drug treatment. The ideal antimalarial should destroy sporozoites soon after they are inoculated into the vertebrate host by the mosquitoes. However, no effective prophylactic antisporozoite drug is currently in use. Medicinal plants that hamper sporozoite development in host cells have been reported and these plants appear to act as prophylactics, as further discussed below.

Merozoites are liberated as merosomes from liver cells and then bud off from the hepatocytes to invade and develop in red blood cells (RBCs) (Sturm et al. 2006). In the RBCs, the parasites undergo asexual multiplication by schizogony and release merozoites, which invade other RBCs, thereby reinitiating the blood-stage cycle (Greenwood et al. 2008). The infected RBCs (iR$\mathrm{BCs}$ ) are responsible for the disease symptoms, i.e., high and periodic fever (paroxysms), headaches (common to all human malaria species) and anaemia. The symptoms of $P$. falciparum include cerebral malaria and respiratory distress (life-threatening manifestations that are related to iRBC cytoadherence on microvascular endothelial cells), blockage of deep capillaries with neurological symptoms and death. The pathogenesis of severe malaria is not completely understood, although proinflammatory cytokines are known to be involved 
(Clark et al. 2006) and these cytokines contribute to the suppression of erythropoiesis, particularly in infected children (Perkins et al. 2011). Evidence supports the role of type 1 pro-inflammatory cytokines that increase the expression of adhesion molecules on vascular endothelium and iRBC sequestration (Schofield \& Grau 2005). Experimental data demonstrate that E6446, a synthetic antagonist of nucleic acid-sensing tool-like receptors (TLRs), diminishes the activation of TLR9 and prevents the increased production of cytokines in response to Plasmodium infections, consequently preventing severe malaria symptoms (Franklin et al. 2011).

In previous reviews, the approaches used for antimalarial drug discovery and development have been discussed (Krettli 2009, Mazier et al. 2009, Wells et al. 2010, Burrows et al. 2011a, b, Muregi et al. 2012) and these methods have since been updated. One of the promising approaches currently being used in the discovery of new antimalarials aimed at drug-resistant parasites and the interruption of the transmission of malaria is the testing of commercially available drugs that are currently prescribed for other indications; if successful, this approach will rapidly accelerate the production of new antimalarials at a lower cost. High-throughput screening (HTS) and molecular modelling (MM) have been successfully used in collaborative projects to select three potential antimalarial candidates (Penna-Coutinho et al. 2011), as discussed below.

Malaria treatment and drug-resistant parasites The discovery of the first antimalarial treatment almost 400 years ago resulted from observations that acutely ill patients were cured of malaria after treatment with infusions of bark obtained from plants growing in the Peruvian Amazon (Graham 1966). Such activity in Cinchona calisaya and Cinchona succirubra plants was later attributed to the alkaloid quinine (QN), which was characterized by French chemists in 1820 . QN remains important for treating complicated P. falciparum malaria despite its toxicity when used for extended periods of time (WHO 2010a, b).

Several 4-aminoquinolines were later synthesised based on the QN ring (Table I). Among them, chloroquine (CQ) is the safest and least expensive drug and most frequently was used to treat malaria worldwide as an essential component of the Global Malaria Eradication Campaign. This campaign, launched in 1955, was based on the treatment of malaria patients using CQ in association with mosquito control measures. In the late 1960s, P. falciparum CQ-resistant strains appeared in Latin America and South East Asia and gradually spread to most endemic regions. This campaign was interrupted in the 1970s. Malaria had been eradicated in a few countries (Karunamoorthi 2011). Most importantly, multidrug and cross-drug resistance among existing antimalarials, mainly the aminoquinolines, were reported. CQ is now used only in drug combinations against $P$. falciparum or as the schizonticide of choice to treat $P$. vivax and other human plasmodia species.

Artemisinin (ART), a sesquiterpene endoperoxide, is a natural product that is isolated from Artemisia an- nua (Asteraceae), a medicinal plant that has been used for over a thousand years in China. ART derivatives are used as antimalarials and have been recommended by the WHO for use in drug combinations [ART-based combination therapies (ACTs)] to treat uncomplicated $P$. falciparum malaria and $P$. vivax in areas of CQ resistance (WHO 2010a, b). Drugs that complement the use of ACT include lumefantrine, amodiaquine, mefloquine (MQ), sulfadoxine-pyrimethamine and antibiotics (Table II). However, reduced susceptibility to ART derivatives has been described in P. falciparum (Dondorp et al. 2009).

The radical cure of $P$. vivax and $P$. ovale requires $\mathrm{PQ}$, an 8-aminoquinoline that prevents late relapses (Wells et al. 2010). PQ also targets the primary liver exo-erythrocytic forms (EEFs), iRBCs and gametocytes; for example, PQ is used to block malarial transmission in Brazil (WHO 2010b) (Table III). However, PQ metabolites cause severe haemolytic anaemia and methemoglobinaemia in patients who are genetically deficient in glucose-6-phosphate dehydrogenase (G6PD) (Carmona-Fonseca et al. 2009). This side effect imposes a pre-screening requirement for G6PD deficiency in $P$. vivax malaria patients and limits PQ use. Tafenoquine, a new drug that targets the liver forms (EEFs and hypnozoites) is currently in clinical trials (Wells et al. 2010) (Table IV).

The control of malaria has become gradually more complex due to the spread of drug-resistant $P$. falciparum strains and drugs that block the transmission of malaria are recommended by the WHO, especially in areas of high P. falciparum transmission. The use of $\mathrm{PQ}$ to control the transmission of malaria in endemic areas requires medical supervision due to the haemolytic toxicity of the drug (WHO 2010a). Interventions to reduce mosquito density, human-vector contact and the vectorial capacity of Anopheles species are not simple (Karunamoorthi 2011). Some methods that are available to reduce the transmission of malaria include indoor spraying with insecticides, ultra-low volume space spraying, the chemical or biological control of larvae and personal protection using repellents or insecticide-treated nets. These methods are hampered by insecticide resistance and the high maintenance costs required to sustain the measures. The development of genetically modified mosquitoes (GMMs) that are resistant to parasite infection (which aims to reduce and/or block Plasmodium transmission) is being undertaken (James et al. 1999, Rodrigues et al. 2008, Isaacs et al. 2011), although the impact of GMMs in the field must be carefully evaluated prior to widespread use.

Currently, no effective vaccine is available to fight human malaria; however, various antigen formulations are undergoing field trials. In particular, RTS,S/AS01E, a vaccine based on the $P$. falciparum circumsporozoite protein and blood stage parasite proteins, has demonstrated promising results (Cohen et al. 2010, Agnandji et al. 2011, Schwartz et al. 2012). Vaccines based on the anti-merozoite surface protein of blood stages $(\mathrm{McCa}-$ rthy et al. 2011) and a transmission-blocking vaccine (Herrera et al. 2007, Arevalo-Herrera 2010, Gregory et al. 2012) are being tested. 
TABLE I

Chemical structure and classification of drugs used for human malaria treatment, mostly combined with artemisine derivatives, monotherapy is no longer recommended

\begin{tabular}{|c|c|c|}
\hline Antimalarial & Structure & Classification \\
\hline Amodiaquine & & 4-aminoquinoline \\
\hline Artemether & & Semi-synthetic endoperoxide \\
\hline Artesunate & & Semi-synthetic endoperoxide \\
\hline Bulaquine $^{a}$ & & 8-aminoquinoline \\
\hline Dihydroartemisinin & & Semi-synthetic endoperoxide \\
\hline Lumefantrine & & Amino alcohol \\
\hline Mefloquine & & Amino alcohol \\
\hline Piperaquine & & Bisquinoline \\
\hline Pyrimethamine & & Diaminopyrimidine \\
\hline Primaquine & & 8-aminoquinoline \\
\hline Quinine & & Amino alcohol \\
\hline Sulfadoxine & & Antibiotic \\
\hline Tafenoquine $^{a}$ & & 8 -aminoquinoline \\
\hline
\end{tabular}

$a$ : bulaquine and tafenoquine are undergoing clinical screening and target the hepatic forms. 
In vitro assays of new antimalarials - Most programs aiming to discover new antimalarials are based on microtests against $P$. falciparum in blood cultures and animal models (Krettli 2009). New methods have replaced traditional assays and various stages of the malaria parasites are currently used. Large-scale drug screening and techniques based on the computer analysis of drug banks are available and being used, as discussed below.

Tests of blood schizonticides - The evaluation of $P$. falciparum drug susceptibility in vitro, formerly based on microscopy, has been replaced by the incorporation of radioactive $\left[{ }^{3} \mathrm{H}\right]$ hypoxanthine into live parasite DNA (Desjardins et al. 1979); however, the need to store radioactive solid wastes for decades, expensive equipment requirements and the need for well-trained technicians restrict the use of this method.

Two enzyme-linked immunosorbent assays are available for drug testing; these assays use monoclonal antibodies that are specific for the parasite enzyme lactate dehydrogenase ( $P f \mathrm{LDH}$ ) (Druilhe et al. 2001) or a parasite histidine-rich protein (HRP)II (Noedl et al. 2002). The assessment of parasite growth is effective in both of these tests. However, the existence of genetic diversity amongst Plasmodium strains interferes with the performance of PfHRP2 tests (Baker et al. 2005).

Methods based on DNA dyes are useful for drug screening and take advantage of the lack of DNA and RNA in erythrocytes. The following nucleic acid dyes are used in P. falciparum tests: (i) SYBR Green I is the most widely used in vitro (Izumiyama et al. 2009) and in vivo (Somsak et al. 2012) and costs less than other dyes, (ii) YOYO-1 is the most sensitive dye and has the advantage of being able to detect low levels of parasitaemia, (iii) the
SYTO series of dyes has increased applicability due to its binding affinities (Jiménez-Díaz et al. 2009), (iv) propidium iodide, which is used with other stains, has a broad emission spectra that limits the range of dye combinations that can be used, (v) acridine orange, a relatively toxic molecule previously used for the diagnosis of human malaria, is laborious to use and has low reproducibility (Grimberg et al. 2008), (vi) the Hoechst dye series, although selective, is of limited use particularly because of its high cost (Grimberg et al. 2008) and (vii) PicoGreen provides reliable results, but is limited by the quenching of its fluorescence by haemoglobin, which confounds the detection of low levels of parasitaemia (Quashie et al. 2006).

Transfected parasites expressing nucleic acid dyes are detected by flow cytometry or fluorescence microscopy and appear to be useful models for drug screening; green fluorescent protein (GFP)-recombinant Plasmodium berghe $i$ and $P$. falciparum parasites have been successfully used (Sanchez et al. 2004, 2007, Wilson et al. 2010).

The inhibition of haemozoin $(\mathrm{Hz})$ ( $\beta$-haematin) formation in vitro is an indirect test that does not require $P$. falciparum blood cultures and has been reported to be useful for antimalarial screening because the majority of 4-aminoquinoline antimalarials test positive, i.e., they inhibit the formation of $\mathrm{Hz}$ crystals. The results, which are measured using enzyme-independent reactions (Dorn et al. 1995, Parapini et al. 2000, Ncokazi \& Egan 2005), are rapidly obtained (a 60-min incubation is used) and were shown to agree across four different laboratories (Ncokazi \& Egan 2005). We have successfully used this test after many attempts to establish a protocol to evaluate the activity of two CQ analogues [monoquinoline (MAQ) and bisquinoline (BAQ)]; both analogues inhibited $\mathrm{Hz}$ formation in vitro, a result that

\section{TABLE II}

Treatment recommended for malaria caused by Plasmodium falciparum drug-resistant parasites with artemisinin-based combination therapies (ACT) for the malaria severe cases and for Plasmodium vivax in regions where a chloroquine lower susceptibility is demonstrated

\begin{tabular}{|c|c|c|c|}
\hline Treatment/route & Malaria type & $\begin{array}{l}\text { Resistance } \\
\text { reported }\end{array}$ & Countries where treatment is adopted ${ }^{a}$ \\
\hline AL/oral & Uncomplicated falciparum & Yes & South America, Africa, Asia (56 countries) \\
\hline $\mathrm{AS}+\mathrm{AQ} /$ oral & Uncomplicated falciparum & Yes & 27 countries, 25 in Africa \\
\hline $\mathrm{AS}+\mathrm{MQ} /$ oral & Uncomplicated falciparum & Yes & South America, Asia, in eight different countries \\
\hline $\mathrm{AS}+\mathrm{SP} /$ oral & Uncomplicated falciparum & Yes & 11 countries, mainly Asia \\
\hline $\mathrm{DHA}+\mathrm{PPQ} /$ oral & Uncomplicated falciparum & Yes & China and South East Asia \\
\hline AS/i.v. or i.m. $+\mathrm{ACT}^{b} /$ oral & Severe falciparum & No & Worldwide \\
\hline QN/i.v. $+\mathrm{ACT}^{b} /$ oral & Severe falciparum & No & Worldwide \\
\hline $\mathrm{ACT}^{b} /$ oral $+\mathrm{PQ}^{\mathrm{c}} /$ oral & CQ resistant $P$. vivax & No & $\begin{array}{l}\text { Where } \mathrm{ACT}^{a} \text { has been adopted } \\
\text { for falciparum malaria treatment }{ }^{d}\end{array}$ \\
\hline Artemisinin derivatives $+\mathrm{PQ}$ /oral & Severe vivax & No & Worldwide \\
\hline
\end{tabular}

$a$ : schedule used as first or second-line treatment; $b$ : artemether + lumefantrine (AL), artesunate (AS) + amodiaquine (AQ), AS + mefloquine (MQ), AS + sulfadoxine/pyrimethamine (SP), dihydroartemisinin (DHA) + piperaquine (PPQ); $c$ : in $P$. vivax, the use of primaquine (PQ) aims radical cure of the late relapses; $d$ : Solomon Islands, Vanuatu, Papua New Guinea, Brazil and Indonesia (Bassat et al. 2011); i.m.: intramuscular injection; i.v.: intravenous injection; QN: quinine. Adapted from WHO (2010a, b, 2011). 
was further supported by docking tests; the interactions with dimeric haematin and the inhibition of haeme polymerisation were dose-dependent (Aguiar et al. 2012).

Several in vivo tests that use animal models are available; all require the approval of protocols regarding the ethical issues for animal use (Krettli et al. 2009). In the 4-day suppressive test, drug activity is measured based on the inhibition of $P$. berghei parasitaemia in comparison with untreated control mice, as described by Peters (1965).

Drugs that act on liver stages and block the transmission of malaria - The primary asexual development of Plasmodium yoelii or $P$. berghei sporozoites in mice or $P$. falciparum in monkeys has also been reproduced in cultured hepatoma cells; however, few laboratories produce these sporozoite stages in Anopheles mosquitoes. When available, the tests are useful tools to investigate drug activity against pre-erythrocytic stages of the parasites (Krettli et al. 2009, Mazier et al. 2009). The use of GFP sporozoites would be useful in protocols because this approach would allow the parasite route to be followed from the site of inoculation to the liver cells (Gueirard et al. 2010), thus elucidating where the parasite is targeted by the antimalarials. The anti-sporozoite activity of two medicinal plants, Ampelozyziphus amazonicus and Strychnopsis thouarsii, has been demonstrated; these drugs were used in malaria-endemic areas of Brazil (AndradeNeto et al. 2008, Krettli et al. 2001) and Madagascar (Carraz et al. 2006), as discussed below.

An indirect assay that measures the activity of new compounds that target hypnozoites was described many years ago based on the rationale that gametocytes and hypnozoites share certain characteristics. Both have a long period of latency, do not proliferate or differentiate and are killed by PQ and other 8-aminoquinolines (Gwadz et al. 1983). The result was further confirmed in our work using Plasmodium gallinaceum sporogony in mosquitoes that were blood-fed on chickens with low parasitaemia (Carvalho et al. 1992). Several new naphtoquinone analogues were tested in parallel with PQ and crude extracts of A. amazonicus (a plant often used against malaria in the Amazon); however, only PQ inhibited oocyst formation. Several new PQ derivatives (Neuenfeldt et al. 2011) were tested using the same protocol. Three among 15 compounds tested inhibited sporogony in the mosquito vector and all 15 tested were active against $P$. falciparum-iRBCs (AU Krettli et al., unpublished observations).

An assay that employs a GFP chimera of the early sexual P. falciparum blood stage protein (Pfs16), as a marker for commitment to gametocytogenesis, was used to assess the activity of various compounds against gametocytes. The use of a transgenic parasite (3D7GFP16B) in cultures allowed for the identification of asexual parasites that will differentiate into gametocytes (Dixon et al. 2009) in cultures containing conditioned media, i.e., those harvested from $P$. falciparum cultures (Williams 1999). The obtained gametocytes were sorted based on the expression of the GFP reporter gene and used for the assay; gametocytes were exposed to test or control drugs (24-48 h) and the results were measured using the ATP-based bioluminescent assay to detect and quantify the viable gametocytes (Peatey et al. 2012).

TABLE III

Specificity of antimalarial drugs against the malaria parasite stages and drug resistance

\begin{tabular}{|c|c|c|c|c|c|}
\hline \multirow[b]{2}{*}{ Antimalarial } & \multicolumn{4}{|c|}{ Parasite targeted stage } & \multirow{2}{*}{$\begin{array}{l}\text { Drug resistance reported } \\
\text { in Plasmodium falciparum }\end{array}$} \\
\hline & EEF & HP & iRBC & GM & \\
\hline Amodiaquine & & & - & & Yes \\
\hline Artemisinins & & & - & - & No \\
\hline Atovaquone & - & & - & - & Yes \\
\hline Chloroquine & & & - & & Yes \\
\hline Clindamycin & - & & - & & No \\
\hline Doxycycline & - & & - & & No \\
\hline Lumefantrine & & & - & & No \\
\hline Mefloquine & & & - & - & Yes \\
\hline Primaquine & - & - & - & - & Yes \\
\hline Proguanil & - & & - & - & Yes \\
\hline Pyrimethamine & - & & - & - & Yes \\
\hline Pyronaridine & & & - & - & Yes \\
\hline Quinine & & & - & & No \\
\hline Sulfadoxine & & & - & - & Yes \\
\hline Tetracycline & - & & - & & No \\
\hline
\end{tabular}

EEF: exoerythrocytic forms from the primary sporozoite development hepatocytes; GM: sexual stages; HP: hypnozoites; iRBC: the erythrocytic forms responsible for the disease. Adapted from Mazier et al. (2009). 
MM in the discovery of antimalarials - MM techniques, including virtual library screening (VLS) and docking studies, have been employed in theoretical medicinal chemistry to discover antimalarials (Luzhkov et al. 2007, Mugnaini et al. 2007). VLS is used to identify chemical structures in the parasite that are likely to bind to the candidate drug, thereby significantly reducing the number of compounds for experimental validation using enzymatic and/or cell-based assays (Kortagere et al. 2010). The results of chemical database querying are refined using docking programs with ligand-receptor algorithms that are able to rapidly process a large number of compounds. The programs Gold ${ }^{\circledR}$ (Luzhkov et al. 2007), FlexX (DeLisle et al. 2001) and Molegro Virtual $\operatorname{Docker}^{\circledR}$ (MVD) (Morris et al. 1998) assess the best conformations of each candidate in terms of the energy and positioning. These programs optimise interactions in the active site and allow for the discovery of novel pharmacophoric groups. New drugs are designed based on previous leads and the stabilities of the ligands inside the binding pockets are further verified using molecular dynamics simulations. A large variety of new antimalarial candidates has been identified using MM among new and well-established drug targets, such as enzymes involved in the folate cycle (SHMT and DHFRTS) (França et al. 2004, 2005, 2006, da Silva et al. 2010), LDH (Penna-Coutinho et al. 2011), enoyl-acyl carrier protein reductase (ENR) (Nicola et al. 2007), protein kinases (Keenan et al. 2005), cysteine proteases (Shah et al. 2011), topoisomerases (Roy et al. 2011) and spermidine synthase (SpdSyn) (Jacobsson et al. 2008).
Hundreds of new potential inhibitors of $P f \mathrm{LDH}$ were selected using VLS and 15 were submitted to docking studies using $\mathrm{MVD}^{\circledR}$. Those compounds showing the lowest binding energies, as well as the commercially available compounds itraconazole, atorvastatin and posaconazole, were tested in vitro against $P$. falciparum and found to be active in CQ-resistant parasites (PennaCoutinho et al. 2011).

Abagyan et al. (1994) used the Internal Coordinate Mechanics program to screen the ChemBridge Express database (chembridge.com/screening libraries/) for chemical compounds that fit into the binding pocket of $P f$ ENR. This search yielded 750 compounds with scores better than -50. A further theoretical absorption, distribution, metabolism and excretion (ADME) prediction yielded 169 compounds, which were experimentally tested using a $P f$ ENR enzyme inhibition assay; 16 compounds showed greater than $45 \%$ inhibition of $P$. falciparum growth at $500 \mu \mathrm{M}$ (Nicola et al. 2007).

Novel binders to the active site of $P$. falciparum SpdSyn (PfSpdSyn), an enzyme involved in the polyamine pathway, were selected using VLS and experimentally tested for parasite binding. Among 2.8 million structures that were tested, representing approximately three million commercially available compounds, 28 were selected for nuclear magnetic resonance testing for binding to $P f \operatorname{SpdSyn}$. The compounds were predicted to target the amino substrate binding pocket and thus exhibited stronger binding upon the addition of methylthioadenosine (Wiesner et al. 2002).

Strategies used to discover new antimalarial drugs - A search based on medicinal plants and biodiversity

TABLE IV

Antimalarials under clinical trials and their parasite stage targets

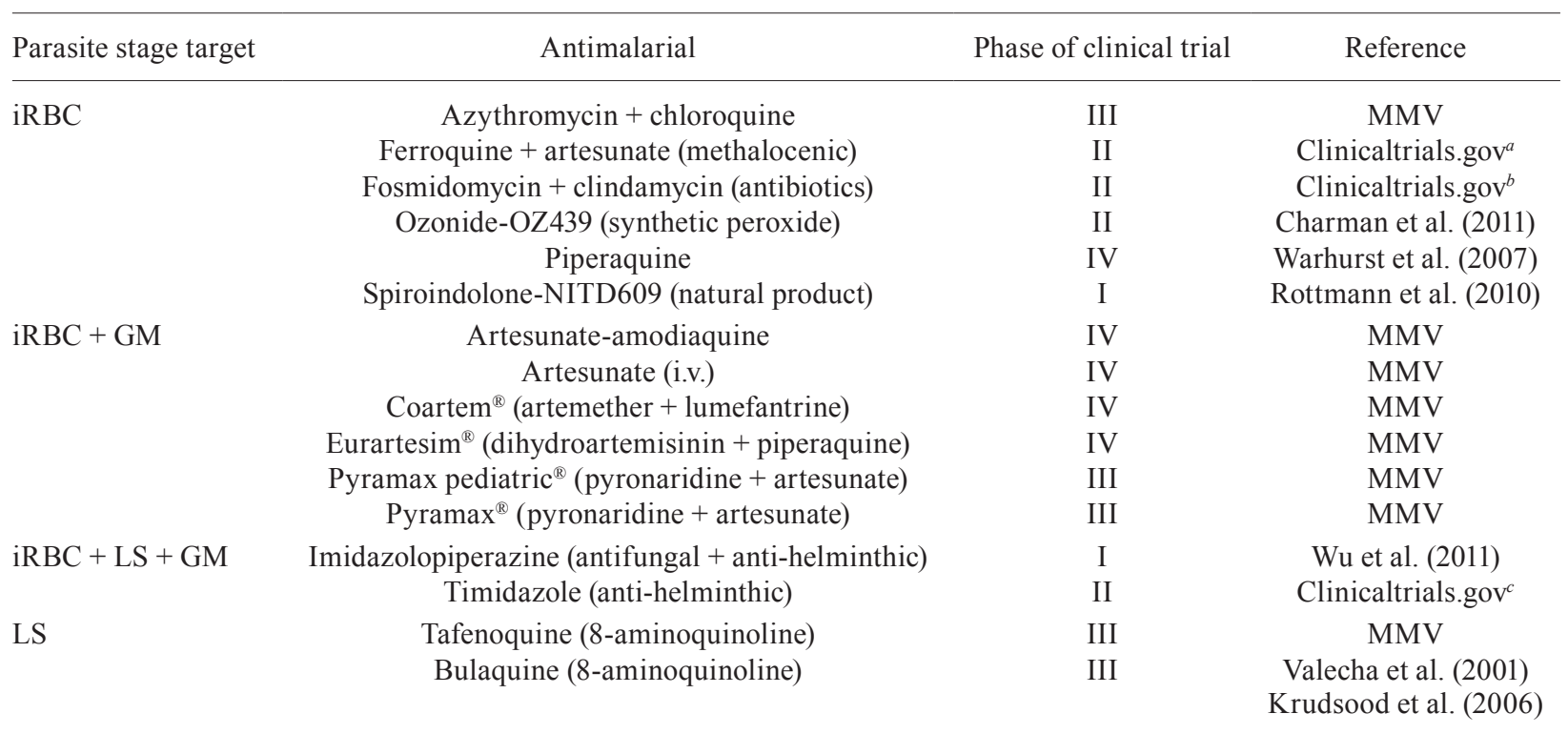

$a$ : clinicaltrials.gov/ct2/show/NCT00988507; $b$ : clinicaltrials.gov/ct2/show/NCT01361269 and clinicaltrials.gov/ct2/show/ NCT00214643; $c$ : clinicaltrials.gov/ct2/show/NCT00811096; GM: gametocytes; i.v.: intravenous injection; iRBC: infected red blood cells; LS: liver stages; MMV: Medicines for Malaria Venture (mmv.org/research-development/science-portifolio). 
- In Africa, herbal products are widely used to treat malaria (Adebayo \& Krettli 2011), although they are not used as extensively in Latin America and other parts of the world. Our group has participated in the search for the active anti-malarial principles in medicinal plants of Brazil, mainly inspired by the success of two longestablished drugs: (i) QN obtained from plants of Latin American origin (Cinchona sp. from the Peruvian Amazon) and (ii) ART derivatives isolated from A. annua, a medicinal plant that has been used for millennia in China for the treatment of malaria and fever (Carvalho \& Krettli 1991, Krettli 2009, Krettli et al. 2009).

We have confirmed the antimalarial activity of extracts and fractions from Cecropia pachystachya (Cecropiaceae) (Supplementary data), a plant species largely used to treat fever (including that caused by malaria parasites) and as food by native indigenous populations in the Amazon Region of Latin America (Uchoa et al. 2010). Crude extracts of the plant roots were found to be active against $P$. falciparum in vitro and against $P$. berghei blood-induced infections in mice. Beta-sitosterol and tormentic acid have been purified from the active fractions and both compounds showed intense in vitro activity. All Cecropia plant extracts and fractions had low, if any, toxicity; thus, a high therapeutic index was observed with some fractions. Therefore, this species may be useful as a phytotherapic compound against human malaria.

Extracts of Bidens pilosa, another medicinal plant that has been used against fevers in general, are active against malaria parasites in vivo and in vitro; flavonoids and polyacetylenes present in this and several other Bidens spp have proven to be active (Brandão et al. 1997, AndradeNeto et al. 2004). Interestingly, B. pilosa was validated for human use by the Ministry of Health in Brazil (portal. saude.gov.br/portal/arquivos/pdf/RENISUS_2010.pdf). Physalis angulata extracts were shown to exhibit intense antimalarial activity and potent immunomodulatory and anti-inflammatory activities (McKerrow et al. 1993, Ridley 2002, Murata \& Goldberg 2003, Newman \& Cragg 2007, Sá et al. 2011, Willcox 2011).

Approximately $50 \%$ of other species of medicinal plants that are commonly used in Brazil have a demonstrated activity against malaria parasites (Carvalho et al. 1991, Brandão et al. 1997, Andrade-Neto et al. 2007). These results affected our research on plants. Recently, species that have been used elsewhere against malaria, such as in Nigeria and other African countries, have been reviewed (Adebayo \& Krettli 2011); however, the only species that we tested, Coccus nucirefa, had little, if any, activity (Adebayo et al. 2012).

In attempts to find an ideal alkaloid to replace QN, we have tested dozens of crude extracts from Cinchona-like medicinal plants (falsas-quinas in Portuguese) for use against malaria and fever and as body stimulants; however, most were found to be inactive in experimental models (unpublished observations). The characteristic bitter taste is taken as an indication of the therapeutic activity of falsas-quinas and healers sell these plants as dried samples in open-air markets and natural products stores. In all cases, plant identification is difficult (Fig. 1A) and buyers must rely on the seller's recommendations.
The ethanolic extract from Remijia ferruginea, a falsa-quina that is endemic in Brazil, was found to be active against malaria parasites, among three species of malaria parasites tested (Andrade-Neto et al. 2003). $R$. ferruginea bark infusions were widely used to treat human malaria in the Amazon before CQ was available as a surrogate for the Peruvian Cinchona species, which is not found in Brazil. Twenty-six dried plant samples were acquired in markets as falsas-quinas in Minas Gerais (MG) (Estrada Real) and ethanolic extracts were prepared and tested in mice with $P$. berghei. Of these extracts, one reduced parasitaemia by $>40 \%$ and was also active against $P$. falciparum in vitro (IO Freitas \& AU Krettli, unpublished observations).

Other natural products such as fungi are used as sources of new drugs, from which secondary metabolites that have anti-malarial activity can be isolated. Pycnidione, isolated from the marine fungus Phoma sp., has been shown to exhibit significant activity against $P$. falciparum. Pycnidione is structurally similar to atovaquone, an ingredient of the antimalarial medication Malarone ${ }^{\circledR}$, which is comprised of atovaquone and proguanil hydrochloride (Wright \& Lang-Unnasch 2005). Molecules isolated from the marine sponge Plakortis simplex, such as polyketide cycloperoxides, and from the sponge Xestospongia sp., such as xestoquinone, have antiplasmodial activity (Botté et al. 2012), as do compounds taken from fertile soils, which exhibit sesquiterpene-related antimalarial activity (Koeni 2003).

Compounds with anti-sporozoite and/or anti-primary liver stage activity have been found in extracts of the medicinal plant $A$. amazonicus ("Indian bear"), which is used in the Brazilian Amazon (Fig. 1B) (Krettli et al. 2001). A. amazonicus was the most cited plant species in recent ethnobotanical surveys in the state of Amazonas (AM) (de Oliveira et al. 2011). We found no activity in crude extracts of this plant and/or in their fractions against $P$. falciparum in cultures or against rodent malaria caused by $P$. berghei infected erythrocytes in mice. However, ethanolic plant fractions were active against $P$. berghei sporozoite-induced infections in mice in a dosedependent manner (Fig. 2). The ethanolic plant extracts also inhibited the exo-erythrocytic development of $P$. berghei sporozoites in vitro (Andrade-Neto et al. 2008). The chemical compound responsible for the anti-sporozoite activity remains to be identified to develop a new antimalarial that is useful for malaria prophylaxis.

Another medicinal plant, Strychnopsis throuasi, which is used in malaria-endemic areas of Madagascar, has been studied and found to be highly efficient against sporozoite-induced malaria in mice, although this plant was inactive against plasmodia blood stages (Carraz et al. 2006). This plant species also appears to be ideal for malaria prophylaxis and a morphinan-like alkaloid, tazopsine, has been isolated and found to be responsible for the anti-sporozoite activity against $P$. falciparum in hepatoma cell cultures and against $P$. berghei sporozoite infections in mice. Thus, tazopsine may represent a good candidate for human malaria prophylaxis.

Drug combinations and hybrids used in antimalarial chemotherapy - The use of combinations of existing an- 
timalarials with known pharmacokinetic and pharmacodynamic profiles optimises the antimalarial therapeutic efficacy and decreases or delays the risk of selecting resistant parasites. Drugs used in combination must have complementary mechanisms of action, synergistic activity and no cross-chemical interactions and must be free from side effects and affordable.

Atovaquone, a naphtoquinone that is highly active in vitro against blood forms of $P$. falciparum and in animal models, resulted in a low cure rate in human malaria trials and selected parasite mutants with reduced drug susceptibility if used alone. However, when combined with proguanil hydrochloride (Malarone ${ }^{\circledR}$ ), atovaquone is recommended by the WHO for uncomplicated malaria in travellers returning to non-endemic countries (WHO 2010b).

Combinations based on ART (WHO 2010b) are listed in Table II. Combinations of MQ and artesunic acid with ciprofloxacin, which are experimentally active in vitro against P. falciparum-iRBCs, appear promising (Andrade et al. 2007). The derivatisation of the fluoroquinolone ciprofloxacin enhanced the in vitro activity and yielded compounds that were 10-100-fold more active than ciprofloxacin (Dubar et al. 2009); chalcones combined with ART (Bhattacharya et al. 2009) and pyronaridine combined with artesunate (AS) (Tshefu et al. 2010) and dihydroartemisinin-piperaquine (Menan et al. 2011) showed intense activity, with the latter exhibiting advantages over artemether-lumefantrine in human malaria.

The design of antimalarials based on the covalent linking of drugs into a single hybrid molecule is a relatively new approach and the resulting molecule tends to be more effective than the isolated components. A series of hybrids containing drugs with different biological functions, distinct pharmacophores, reduced toxicity and improved activity (as compared to the isolated compounds) are being developed.

The ART hybrid, 1,2,4,5-tetraoxane (RKA 182), is considered to be an outstanding antimalarial candidate with the advantages of enhanced stability, lower toxicity and improved biopharmaceutical properties (ADME)

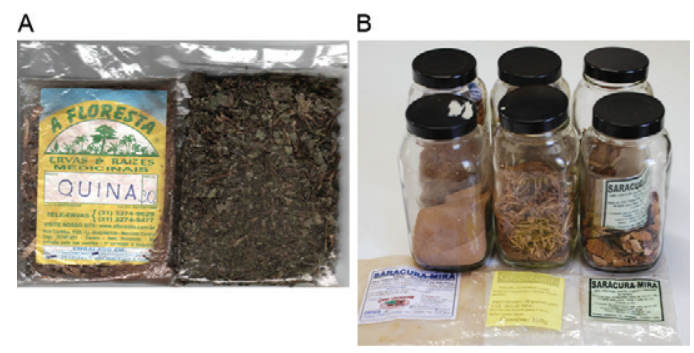

Fig. 1: medicinal plants sold by healers in opened markets: A: a dried sample of a cinchone-like plant (quina) acquired in city markets; B: Ampelozizyphus amazonicus (Rhamnaceae) in the form of dried roots (photo by MGL Brandão) sold in the Amazon markets under the names of "Indian beer" or Saracura-mirá and largely used against malaria as a cold infusion in some malaria regions; although the plant extract of this species was inactive against malaria blood stages, in several experimental models, including against Plasmodium falciparum in vitro, it blocks the sporozoites development in vivo and in vitro, as shown in Fig. 2. compared to the semisynthetic antimalarial ART (O’Neill et al. 2010).

The hybrid molecule MEFAS, which is derived from MQ and AS, is more effective and less toxic than the combination of MQ and AS, as shown using an experimental in vitro test with $P$. falciparum and in animal models (de Pilla Varotti et al. 2008). The hybrid compound comprises dual functions and, as in acridone hybrid molecules, the drug is based on the aminoquinoline ring. The acridone T3.5 (3-chloro-6-(2-diethylamino-ethoxy)-10-(2-diethylamino-ethyl)-acridone) targets drug-resistant strains at nanomolar concentrations and represents an innovative strategy for developing antimalarial drugs (Kelly et al. 2009).

Compounds that are chemically related to known antimalarials - An important strategy in drug design is the chemical modification of known antimalarials, such as 4-aminoquinolines (Hocart et al. 2011). The alkylamine sidechains allow for structural modification of the 4-aminoquinolines, resulting in compounds that have different lipophilicity and drug-resistance profiles (Kouznetsov \& Gómez-Barrio 2009). Substitutions on the distal amino sidechain of CQ derivatives increase the activity and decrease the cross-resistance to CQ (Stocks et al. 2002).

Among the CQ analogues that have been synthesised by linking 4,7-dichloroquinoline with monoalkynes
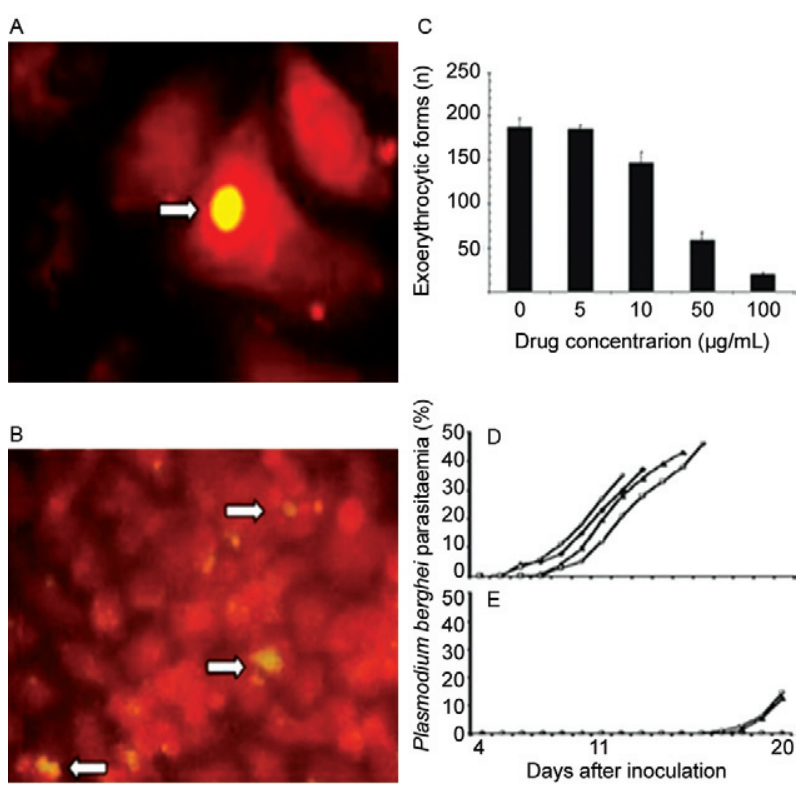

Fig. 2: Plasmodium berghei sporozoite development in hepatoma cells (HepG2) in a drug-free culture medium (A, arrow). Ethanolic extract fractions of the medicinal plant Ampelozizyphus amazonicus inhibited $P$. berghei sporozoite development in vitro (B, arrows) in a dose-dependent fashion $(\mathrm{C})$. It also protected mice against a $P$. berghei sporozoite challenge, as compared to control non-treated mice that developed high parasitaemia (D) after a short pre-patent period (PPP); among the pre-treated group receiving $400 \mathrm{mg} / \mathrm{kg}$ of the ethanolic extracts, two in four mice became infected. A significantly long malaria PPP and rather low parasitaemias (E) occurred at the second week of infection [adapted from Andrade-Neto et al. (2008)]. 
and dialkynes, 12 compounds have demonstrated activity against $P$. berghei in mice, especially those with methylene groups in the sidechain (de Souza et al. 2011). Two new CQ analogues, MAQ and BAQ, in which the 4-aminoquinoline pharmacophore group and protonaccepting sites are maintained to increase the bioavailability of the compound in the digestive vacuole of the parasite, were active in vitro against $P$. falciparum at nanomolar concentrations and exhibited a therapeutic index similar to that of CQ (Aguiar et al. 2012).

Ferroquine, a methalocenic CQ analogue, that is considered to be the most advanced organometallic antimalarial (Delhaes et al. 2002), is in clinical trials for the treatment of uncomplicated malaria (clinicaltrials.gov/ ct2/show/NCT00811096) (Table IV).

Drugs available to treat other human diseases - The testing drugs that are indicated against other diseases provides the opportunity to find new clinical uses for licensed drugs that are approved for human use and for which safety and pharmacokinetic information is previously available. The purposes of this approach are to lower the costs and shorten the timeframe of product development. Good examples of this strategy include the existing anti-human immunodeficiency virus (HIV) protease inhibitor drugs, among which lopinavir has proven to be potent and promising against malaria parasites (Nsanzabana \& Rosenthal 2011). The mechanism of action of HIV protease inhibitors against malaria is attributed to the inhibition of the food vacuole protease, plasmepsin II (Parikh et al. 2006). Tipranavir, although less active against malaria, demonstrates gametocytocidal activity and thus should have a significant effect on the transmission and control of malaria (Peatey et al. 2010).

Agents such as posaconazole (an inhibitor of ergosterol biosynthesis), itraconazole (an antifungal agent) and atorvastatin (widely used to reduce cholesterol levels) have proven to be active against $P$. falciparum blood stage parasites in vitro and against $P$. berghei-infected mice (Penna-Coutinho et al. 2011). These compounds are candidates for clinical trials in combination with other antimalarials.

The antifungal and anti-helminthic compound imidazolopiperazine, which is active against liver stages of Plasmodium, may prevent clinical disease by providing prophylactic protection. The drug has also presented significant in vivo antimalarial activity against blood-stage parasites (Meister et al. 2011).

Several drugs that were originally developed as antibiotics are useful for the treatment of human malaria in combination with antimalarials. Sulfadoxine (S), a synthetic antimicrobial agent, interferes in the folate synthesis pathway (which is essential for DNA and RNA synthesis) of malaria parasites when combined with pyrimethamine $(\mathrm{P})$. However, with the emergence of resistant $P$. falciparum strains, $\mathrm{SP}$ is no longer recommended against malaria (WHO 2010b). Clindamycin, which is usually prescribed to treat anaerobic bacterial infections, is also active as an antimalarial and has been used in clinical studies either alone or in combination with QN and CQ (Lell \& Kremsner 2002). As a monotherapy, however, the use of clindamycin is limited due to its slow onset of action; studies conducted to evaluate its effectiveness in combination with QN were not conclusive (Obonyo \& Juma 2012). Clindamycin is recommended in combination with AS as a second-line antimalarial treatment and in combination with other antibiotics, such as tetracycline and doxycycline (WHO 2010a).

Fosmidomycin, a natural antibacterial agent, has successfully been used in clinical studies against uncomplicated P. falciparum; however, recrudescent infections were observed in treated subjects (Wiesner et al. 2003). Fosmidomycin inhibits 1-deoxy-D-xylulose 5-phosphate reductoisomerase, an enzyme involved in the synthesis of isoprenoids, which is essential for parasite survival but not for the human host (which synthesise isoprenoids through the mevalonate pathway) (Wiesner et al. 2003). Azithromycin, a macrolide antibiotic, affects $P$. falciparum growth by targeting the apicoplast $50 \mathrm{~S}$ ribosomal subunit and inhibits protein synthesis in this organelle (Sidhu et al. 2007). Geldanamycin, a benzoquinone ansamycin antibiotic, also shows antimalarial activity by inhibiting the heat shock protein, HSP90, a molecular chaperone that is important for the maturation of proteins that promote the survival and the growth of dividing cells (Mout et al. 2012).

In vitro HTS - Drug discovery by HTS allow the largescale testing of potentially active products ("hits") by optimising and accelerating the identification of "lead" molecules for further development. Various automated HTS bioassay systems are used to screen synthetic and natural products to an extent not possible using conventional technologies. Further evaluation of drug activities selected using HTS can be assessed against Plasmodium parasites in culture or by biochemically screening targets.

Several methods are available to screen for parasite viability and are suitable for HTS technology. The most often used methods are based on the measurement of DNA content in recombinant strains of malaria parasites using SYBR green (Smilkstein et al. 2004), GFP (Wilson et al. 2010) and 4',6'-diamidino-2-phenylindole (Duffy \& Avery 2012), or in a stably expressed cytoplasmic firefly luciferase parasite strain (3D7-luc) (Lucumi et al. 2010, Che et al. 2012).

The biochemical approach based on structure-based drug design holds promise for the search for lead-like antimalarials. This approach is based on a defined target such as a protein and/or enzyme that is necessary for parasite survival, as identified in binding assays that screen for inhibitors. The integration of HTS with a computational methodology (namely, virtual HTS) can be applied to in silico drug selection from compound libraries. This method is based on the binding affinity of the target receptor for the test compounds (i.e., molecular docking).

New antimalarial drugs undergoing clinical trials - Several new chemical groups with promising antimalarial activity are now undergoing clinical trials. Certain imidazolopiperazines that are experimentally active against the blood, liver and gametocyte stages of $P$. falciparum are active in malaria models and have a 
safe profile were selected for clinical trials (Wu et al. 2011). The spiroindolone compound NITD609, a potent inhibitor of $P$. falciparum selected in a phenotypic HTS of natural products, is also undergoing Phase I trials (Rottmann et al. 2010). The ozonide OZ439, a synthetic peroxide antimalarial that is designed to provide a single oral dose to cure human malaria, is currently undergoing Phase II trials (Charman et al. 2011).

New medicines in Phases III/IV clinical trials include the following: (i) a fixed-dose combination of azithromycin and CQ for intermittent preventive treatment in pregnant women, (ii) tafenoquine, an 8-aminoquinoline with demonstrated activity against dormant liver forms of $P$. vivax (hypnozoites) in vitro and blood stages in the acute disease, (iii) Pyramax ${ }^{\circledR}$ paediatric, a child-friendly granule formulation of the ACT Pyramax ${ }^{\circledR}$, is in Phase IV trials, (iv) Coartem ${ }^{\circledR}$ dispersible (artemether-lumefantrine), ASAQ $^{\circledR}$ (Artesunate-Amodiaquine, Winthrop), Artesunate for injection and Eurartesim ${ }^{\circledR}$ (dihydroartemisininpiperaquine) (Medicines for Malaria Venture) and (iv) piperaquine, a 4-aminoquinoline that acts similar to CQ (Warhurst et al. 2007). Although bulaquine, an 8-aminoquinoline, has been approved to treat $P$. vivax malaria in India, its safety has not been assured using large clinical trials (Valecha et al. 2001, Krudsood et al. 2006). Drugs derived from medications against other diseases are undergoing clinical trials as antimalarials (Table IV).

Concluding remarks - Malaria remains a major health problem, especially now that $P$. falciparum and $P$. vivax have also become resistant to CQ and evidence of $P$. falciparum resistance to ART has been reported. Commitment to the eradication of malaria, together with substantial financial support from national and international agencies, has furthered the selection of various molecules, some of which will hopefully help to interrupt disease transmission. Among the new drugs undergoing clinical trials, ferroquine, tafenoquine and bulaquine have shown promising results.

The overall goal regarding the control of malaria is to expand the drug arsenal with a new generation of molecules that target the various life stages of the parasites, i.e., asexual drug-resistant parasites, gametocytes and liver forms, as well as hypnozoites, which cause late relapses of $P$. vivax. Parallel projects intended to diminish poverty among less-privileged populations need to be concentrated in areas where the transmission of malaria is endemic. However, the global economic crisis, political conflicts experienced by African countries where malaria is highly endemic and inadequate health care are likely to affect funding for the further support of drug discovery and poverty alleviation.

Different methodologies are available to aid in the search for new antimalarials. The most frequently used technology is in vitro drug screening with blood-stage $P$. falciparum parasites maintained in continuous cultures. Large-scale drug testing uses $\left[{ }^{3} \mathrm{H}\right]$ hypoxanthine incorporation, which is a relatively simple assay; however, this assay requires radioactive reagents, thus imposing the need for surrogate methods. Two tests were developed that use specific monoclonal antibodies, either to parasite enzymes or a HRP, and both have proven useful and reproducible. Other tests use genetically modified parasites and parasite nucleic acid stains for DNA (e.g., SYBR Green I, the most cost-effective choice, YOYO-1, the most sensitive dye, and the SYTO series, with high binding affinities) have been developed.

$\mathrm{Hz}$ formation is a critical step for the survival of the malaria parasite and the basis for in vitro $\mathrm{Hz}$ inhibition, which is a simple and inexpensive indirect assay used for drug screening. It is hoped that once this assay is well standardised, it could also provide clues regarding the mechanism of the action of drugs.

HTS are especially useful in drug discovery and allow for the rapid analysis of potentially biologically active compounds. Millions of new molecules targeting blood stages of $P$. falciparum have been selected in recent years and are available in drug banks; improved VSLs, which benefit from computer analysis using refined docking programs, are also helpful. However, the confirmation of the usefulness of such molecules in the treatment of human malaria depends on their direct validation against malaria parasites. Commercially available drugs for human use, such as itraconazole, atorvastatin and posaconazole, which have already been proven to inhibit $P$. falciparum growth in cultures, represent an important source of new drug combinations that can be used to treat drug-resistant parasites. The chemical modification of available antimalarial drugs to enhance their pharmacodynamics and pharmacokinetic properties (e.g., absorption, metabolism, bioavailability, lipophilicity and drug distribution) is also a powerful tool, as is the hybridization of highly active antimalarial drugs. Imidazolopiperazine and timidazole, which have passed toxicological and pharmacological tests and have been found to be effective in humans against other pathologies, are currently under clinical trials after their activity against the liver forms and blood stages of malaria parasites were demonstrated.

Tafenoquine and bulaquine are in initial clinical trials using $P$. vivax malaria; these drugs target the primary liver stages of sporozoites and the late developing hypnozoite forms. The large-scale screenings of other drugs that are less toxic than PQ are not trivial to accomplish; thus, this technique remains an ongoing challenge that is restricted by the limited availability of in vivo models and/ or sporozoite cultures that reproduce hypnozoites. Sporozoite production is difficult, expensive and complex, thus limiting their use to a few laboratories worldwide.

Recently, important funds have become available through international and national agencies, as well as the pharmaceutical industry and communities committed to anti-malaria programs. Through projects supported by Brazilian agencies [The National Council for Scientific and Technological Development, The Minas Gerais State Research Foundation and Oswaldo Cruz Institute (Fiocruz), in particular], we have recently worked in close collaboration with senior scientists (mainly chemists) and built a network within research institutions (Fig. 3). In the area in which malaria is endemic, two collaborating groups are participating in the search for new antimalarials; one group, led by Maria Meneses Pereira (Federal University of Amazonas), is 
located in AM, and the other group, led by Cláudio Nahum Alves (Federal University of Pará), is in the state of Pará. In the Northeast Region, our network collaborators include A Euzébio Santana, Marília FO Goulart and Mario Meneguetti (Federal University of Alagoas), as well as Valter Andrade-Neto (Federal University of Rio Grande do Norte) and Milena Soares (Fiocruz-Bahia). The groups in the Southeast include the following: Lúcia Maria X Lopes (São Paulo State University-state of São Paulo), Carlos Zani and Tânia Alves (Fiocruz-MG), Núbia Boechat and J Mendonça [Fiocruz-state of Rio de Janeiro (RJ)] and Tanos CC França (Military Institute of Engineering-RJ). The groups in the South include Arildo Bráz Oliveira (State University of Maringá-state of Paraná) and Wilson J Cunico (Federal University of Pelotas-state of Rio Grande do Sul). The latter group has synthesized new PQ analogues that are quite potent and we hope to find a new drug among these analogues that is active against the liver forms of malaria.

The resilience and ingenuity of the malaria parasite in preserving itself, whatever the threat, requires the constant evaluation of control programs and searching for new antimalarials. An ideal antimalarial drug combination to replace ACT and halt the spread of resistant parasites is urgently needed. The ozonide OZ439, a synthetic peroxide, is considered promising because it is active in curing uncomplicated malaria in a single

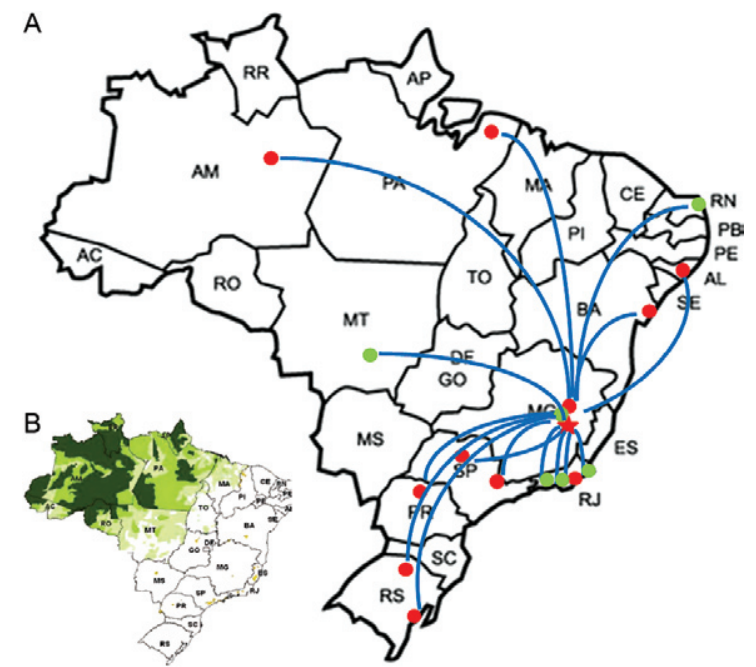

Fig. 3A: a web of chemist collaborators in our multidisciplinary project of antimalarial research and development, supported by Brazilian institutions, in which biological plant extracts and newly synthesised molecules are produced; B: malaria endemic areas in Brazil represented in different intensities of green, according to the Ministry of Health. The darker green represents the highest prevalence and, in white, the areas with no malaria transmission (Source: portal.saude.gov.br). Brazilian states: Acre (AC); Alagoas (AL); Amapá (AP); Amazonas (AM); Bahia (BA); Ceará (CE); Distrito Federal (DF); Espírito Santo (ES); Goiás (GO); Maranhão (MA); Mato Grosso (MT); Mato Grosso do Sul (MS); Minas Gerais (MG); Pará (PA); Paraíba (PB); Paraná (PR); Pernambuco (PE); Piauí (PI); Rio de Janeiro (RJ); Rio Grande do Norte (RN); Rio Grande do Sul (RS); Rondônia (RO); Roraima (RR); Santa Catarina (SC); São Paulo (SP); Sergipe (SE); Tocantins (TO). dose and is currently undergoing clinical trials. Whether OZ439 will control drug-resistant $P$. falciparum parasites in regions where ACT is less effective remains to be demonstrated.

\section{ACKNOWLEDGEMENTS}

To Dr Wilson J Cunico (UFPEL), for critical reading the manuscript, to Dr Maria G Lins Brandão, for the photo (Fig. $1 B$ ), and for the collaboration in the antimalarial search during decades.

\section{REFERENCES}

Abagyan R, Totrov M, Kuznetsov DA 1994. ICM-a new method for protein modeling and design: applications to docking and structure prediction from the distorted native conformation. J Comp Chem 15: 488-506.

Adebayo JO, Krettli AU 2011. Potential antimalarials from Nigerian plants: a review. J Ethnopharmacol 133: 289-302.

Adebayo JO, Santana AE, Krettli AU 2012. Evaluation of the antiplasmodial and cytotoxicity potentials of husk fiber extracts from Cocos nucifera, a medicinal plant used in Nigeria to treat human malaria. Hum Exp Toxicol 31: 244-249.

Agnandji ST, Lell B, Soulanoudjingar SS, Fernandes JF, Abossolo BP, Conzelmann C, Methogo BG, Doucka Y, Flamen A, Mordmüller B, Issifou S, Kremsner PG, Sacarlal J, Aide P, Lanaspa M, Aponte JJ, Nhamuave A, Quelhas D, Bassat Q, Mandjate S, Macete E, Alonso P, Abdulla S, Salim N, Juma O, Shomari M, Shubis K, Machera F, Hamad AS, Minja R, Mtoro A, Sykes A, Ahmed S, Urassa AM, Ali AM, Mwangoka G, Tanner M, Tinto H, D’Alessandro U, Sorgho H, Valea I, Tahita MC, Kaboré W, Ouédraogo S, Sandrine Y, Guiguemdé RT, Ouédraogo JB, Hamel MJ, Kariuki S, Odero C, Oneko M, Otieno K, Awino N, Omoto J, Williamson J, Muturi-Kioi V, Laserson KF, Slutsker L, Otieno W, Otieno L, Nekoye O, Gondi S, Otieno A, Ogutu B, Wasuna R, Owira V, Jones D, Onyango AA, Njuguna P, Chilengi R, Akoo P, Kerubo C, Gitaka J, Maingi C, Lang T, Olotu A, Tsofa B, Bejon P, Peshu N, Marsh K, Owusu-Agyei S, Asante KP, Osei-Kwakye K, Boahen O, Ayamba S, Kayan K, Owusu-Ofori R, Dosoo D, Asante I, Adjei G, Adjei G, Chandramohan D, Greenwood B, Lusingu J, Gesase S, Malabeja A, Abdul O, Kilavo H, Mahende C, Liheluka E, Lemnge M, Theander T, Drakeley C, Ansong D, Agbenyega T, Adjei S, Boateng HO, Rettig T, Bawa J, Sylverken J, Sambian D, Agyekum A, Owusu L, Martinson F, Hoffman I, Mvalo T, Kamthunzi P, Nkomo R, Msika A, Jumbe A, Chome N, Nyakuipa D, Chintedza J, Ballou WR, Bruls M, Cohen J, Guerra Y, Jongert E, Lapierre D, Leach A, Lievens M, Ofori-Anyinam O, Vekemans J, Carter T, Leboulleux D, Loucq C, Radford A, Savarese B, Schellenberg D, Sillman M, Vansadia P, RTS,S Clinical 2011. First results of phase 3 trial of RTS,S/AS01 malaria vaccine in African children. $N$ Engl J Med 365: 1863-1875.

Aguiar AC, Santos R de M, Figueiredo FJ, Cortopassi WA, Pimentel AS, França TC, Meneghetti MR, Krettli AU 2012. Antimalarial activity and mechanisms of action of two novel 4-aminoquinolines against chloroquine-resistant parasites. PLOS ONE 7: e37259.

Andrade AA, de Pilla Varotti F, de Freitas IO, de Souza MV, Vasconcelos TR, Boechat N, Krettli AU 2007. Enhanced activity of mefloquine and artesunic acid against Plasmodium falciparum in vitro and $P$. berghei in mice by combination with ciprofloxacin. Eur J Pharmacol 558: 194-198.

Andrade-Neto VF, Brandão MG, Nogueira F, Rosário VE, Krettli AU 2008. Ampelozyziphus amazonicus Ducke (Rhamnaceae), a medicinal plant used to prevent malaria in the Amazon Region, hampers the development of Plasmodium berghei sporozoites. Int J Parasitol 13: 1505-1511. 
Andrade-Neto VF, Brandão MG, Oliveira FQ, Casali VW, Njaine B, Zalis MG, Oliveira LA, Krettli AU 2004. Antimalarial activity of Bidens pilosa L. (Asteraceae) ethanol extracts from wild plants collected in various localities or plants cultivated in humus soil. Phytother Res 18: 634-639.

Andrade-Neto VF, Brandão MG, Stehmann JR, Oliveira LA, Krettli AU 2003. Antimalarial activity of Cinchona-like plants used to treat fever and malaria in Brazil. J Ethnopharmacol 87: 253-256.

Andrade-Neto VF, da Silva T, Lopes LM, do Rosário VE, de Pilla Varotti F, Krettli AU 2007. Antiplasmodial activity of aryltetralone lignans from Holostylis reniformis. Antimicrob Agents Chemother 5: 2346-2350.

Arevalo-Herrera M, Chitnis C, Herrera S 2010. Current status of Plasmodium vivax vaccine. Hum Vaccin 6: 124-132.

Baker J, McCarthy J, Gatton M, Kyle DE, Belizario V, Luchavez J, Bell D, Cheng Q 2005. Genetic diversity of Plasmodium falciparum histidine-rich protein 2 ( $P f \mathrm{HRP} 2)$ and its effect on the performance of $P f \mathrm{HRP} 2$-based rapid diagnostic tests. $J$ Infec Dis 192: 870-877.

Bhattacharya A, Mishra LC, Sharma M, Awasthi SK, Bhasin VK 2009. Antimalarial pharmacodynamics of chalcone derivatives in combination with artemisinin against Plasmodium falciparum in vitro. Eur J Med Chem 44: 3388-3393.

Botté CY, Dubar F, McFadden GI, Maréchal E, Biot C 2012. Plasmodium falciparum apicoplast drugs: targets or off-targets? Chem Rev 112: 1269-1283.

Brandão MGL, Krettli AU, Soares L, Nery CGC, Marinuzzi HC 1997. Antimalarial activity of extracts and fractions from Bidens pilosa and other Bidens species (Asteraceae) correlated with the presence of acetylene and flavonoid compounds. J Ethnopharmacol 57: 131-138.

Burrows JN, Chibale K, Wells TNC 2011a. The state of the art in anti-malarial drug discovery and development. Curr Top Medic Chem 11: 1226-1254.

Burrows JN, Leroy D, Lotharius J, Waterson D 2011b. Challenges in antimalarial drug discovery. Future Med Chem 3: 1401-1412.

Carmona-Fonseca J, Alvarez G, Maestre A 2009. Methemoglobinemia and adverse events in Plasmodium vivax malaria patients associated with high doses of primaquine treatment. Am J Trop Med Hyg 80: 188-193.

Carraz M, Jossang A, Franetich JF, Siau A, Ciceron L, Hannoun L, Sauerwein R, Frappier F, Rasoanaivo P, Snounou G, Mazier D 2006. A plant-derived morphinan as a novel lead compound active against malaria liver stages. PLoS Med 3: e513.

Carvalho LH, Brandão MGL, Santos D, Lopes JLC, Krettli AU 1991. Antimalarial activity of crude extracts from Brazilian plants studied in vivo in Plasmodium berghei infected mice and in vitro against Plasmodium falciparum in culture. Braz J Med Biol Res 24: $1113-1123$

Carvalho LH, Ferrari W, Krettli A 1992. A method for screening drugs against the liver stages of malaria using Plasmodium gallinaceum and Aedes mosquitos. Braz J Med Biol Res 25: 247-255.

Carvalho LH, Krettli AU 1991. Antimalarial chemotherapy with natural products and chemically defined molecules. Mem Inst Oswaldo Cruz 86 (Suppl. II): 181-184.

Charman SA, Arbe-Barnes S, Bathurst IC, Brun R, Campbell M, Charman WN, Chiu FC, Chollet J, Craft JC, Creek DJ, Dong Y, Matile H, Maurer M, Morizzi J, Nguyen T, Papastogiannidis P, Scheurer C, Shackleford DM, Sriraghavan K, Stingelin L, Tang Y, Urwyler H, Wang X, White KL, Wittlin S, Zhou L, Vennerstrom JL 2011. Synthetic ozonide drug candidate OZ439 offers new hope for a single-dose cure of uncomplicated malaria. Proc Natl Acad Sci 108: 4400-4405.

Che P, Cui L, Kutsch O, Cui L, Li Q 2012. Validating a firefly luciferase-based high-throughput screening assay for antimalarial drug discovery. Assay Drug Dev Technol 10: 61-68.

Clark IA, Budd AC, Alleva LM, Cowden WB 2006. Human malarial disease: a consequence of inflammatory cytokine release. $M a$ lar J 5: 85 .

Cohen J, Nussenzweig V, Nussenzweig R, Vekemans J, Leach A 2010. From the circumsporozoite protein to the RTS,S/AS candidate vaccine. Hum Vacs 6: 90-96.

Cox-Singh J, Singh B 2008. Knowlesi malaria: newly emergent and of public health importance? Trends Parasitol 24: 406-410.

da Silva ML, Gonçalves AS, Batista PR, Villar JDF, Pascutti PG, França TCC 2010. Design, docking studies and molecular dynamics of new potential selective inhibitors of Plasmodium falciparum serine hydroxymethyltransferase. Mol Simulat 36: 5-14.

de Oliveira DR, Costa ALMA, Leitão GG, Castro NG, Santos JP, Leitão SG 2011. Ethnopharmacology study of Saracuramirá (Ampelozizyphus amazonicus Ducke) in the "Quilombola" communities of Oriximiná, Pará state, Brazil. Acta Amaz 41: 383- 392.

de Pilla Varotti F, Botelho AC, Andrade AA, de Paula RC, Fagundes EM, Valverde A, Mayer LM, Mendonça JS, de Souza MV, Boechat N, Krettli AU 2008. Synthesis, antimalarial activity and intracellular targets of mefas, a new hybrid compound derived from mefloquine and artesunate. Antimicrob Agents Chemother 52: 3868-3874

de Souza NB, Carmo AM, Lagatta DC, Alves MJ, Fontes AP, Coimbra ES, da Silva AD, Abramo C 2011. 4-aminoquinoline analogues and its Platinum (II) complexes as antimalarial agents. Biomed Pharmacother 65: 313-316.

Delhaes L, Biot C, Berry L, Delcourt P, Maciejewski LA, Camus D, Brocard JS, Dive D 2002. Synthesis of ferroquine enantiomers: first investigation of effects of metallocenic chirality upon antimalarial activity and cytotoxicity. Chem Bio Chem 3: 418-423.

DeLisle RK, Yu SJ, Nair AC, Welsh WJ 2001. Homology modeling of the estrogen receptor subtype beta (ER-beta) and calculation of ligand binding affinities. J Mol Graph Model 20: 155-167.

Desjardins RE, Canfield CJ, Haynes JD, Chulay JD 1979. Quantitative assessment of antimalarial activity in vitro by a semiautomated microdilution technique. Antimicrob Agents Chemother 16: 710-718.

Dixon MW, Peatey CL, Gardiner DL, Trenholme KR 2009. A green fluorescent protein-based assay for determining gametocyte production in Plasmodium falciparum. Mol Biochem Parasitol 163: 123-126.

Dondorp AM, Nosten F, Yi P, Das D, Phyo AP, Tarning J, Lwin KM, Ariey F, Hanpithakpong W, Lee SJ, Ringwald P, Silamut K, Imwong M, Chotivanich K, Lim P, Herdman T, An SS, Yeung S, Singhasivanon P, Day NP, Lindegardh N, Socheat D, White NJ 2009. Artemisinin resistance in Plasmodium falciparum malaria. N Engl J Med 361: 455-467.

Dorn A, Stoffel R, Matile H, Bubendorf A, Ridley RG 1995. Malarial haemozoin/beta-haematin supports haem polymerization in the absence of protein. Nature 374: 269-271.

Druilhe P, Moreno A, Blanc C, Brasseur PH, Jacquier P 2001. A colorimetric in vitro drug sensitivity assay for Plasmodium falciparum based on a highly sensitive double-site lactate dehydrogenase antigen-capture enzyme-linked immunosorbent assay. Am J Trop Med Hyg 64: 233-241. 
Dubar F, Anquetin G, Pradines B, Dive D, Khalife J, Biot C 2009. Enhancement of the antimalarial activity of ciprofloxacin using a double prodrug/bioorganometallic approach. J Med Chem 52: 7954-7957.

Duffy S, Avery VM 2012. Development and optimization of a novel 384-well anti-malarial imaging assay validated for high-throughput screening. Am J Trop Med Hyg 86: 84-92.

França TCC, Medeiros ALR, Santos ECP, Santos-Filho AO, Villar JDF 2004. A complete model of the Plasmodium falciparum bifunctional enzyme dihydrofolate reductase-thymidylate synthase: a model to design new antimalarials. $J$ Brazil Chem Soc 15: $450-454$

França TCC, Pascutti PG, Ramalho TC, Villar JDF 2005. A threedimensional structure of serine hydroxymethyltransferase in complex with glycine and 5-formyl-tetrahydrofolate. Homology modeling and molecular dynamics. Biophys Chem 115: 1-10.

França TCC, Wilter A, Ramalho TC, Pascutti PG, Villar JDF 2006. Molecular dynamics of the interaction of Plasmodium falciparum and human serine hydroxymethyltransferase with 5-formyl-6hydrofolic acid analogues: design of new potential antimalarials. J Brazil Chem Soc 17: 1383-1392.

Franklin BS, Ishizaka ST, Lamphier M, Gusovsky F, Hansen H, Rose J, Zheng W, Ataíde MA, de Oliveira RB, Golenbock DT, Gazzinelli RT 2011. Therapeutical targeting of nucleic acid-sensing Toll-like receptors prevents experimental cerebral malaria. Proc Natl Acad Sci 108: 3689-3694.

Graham PCC 1966. Historical summary of the discovery of the malaria parasites. In Malaria parasites and other haemosporidia, Blackwell Scientific Publications, Oxford, p. 3-16.

Greenwood BM, Fidock DA, Kyle DE, Kappe SH, Alonso PL, Collins FH, Duffy PE 2008. Malaria: progress, perils and prospects for eradication. J Clin Invest 118: 1266-1276.

Gregory JA, Li F, Tomosada LM, Cox CJ, Topol AB, Vinetz JM, Mayfield S 2012. Algae-produced pfs25 elicits antibodies that inhibit malaria transmission. PLOS ONE 7: e37179.

Grimberg BT, Erickson JJ, Sramkoski RM, Jacobberger JW, Zimmerman PA 2008. Monitoring Plasmodium falciparum growth and development by UV flow cytometry using an optimized Hoechstthiazole orange staining strategy. Cytom A 73: 546-554.

Gueirard P, Tavares J, Thiberge S, Bernex F, Ishino T, Milon G, Franke-Fayard B, Janse CJ, Ménard R, Amino R 2010. Development of the malaria parasite in the skin of the mammalian host. Proc Natl Acad Sci USA 107: 18640-18645.

Gwadz RW, Koontz LC, Miller LH, Davidson Jr DE 1983. Plasmodium gallinaceum: avian screen for drugs with radical curative properties. Exp Parasitol 55: 188-196.

Herrera S, Corradin G, Arévalo-Herrera M 2007. An update on the search for a Plasmodium vivax vaccine. Trends Parasitol 23: $122-128$

Hocart SJ, Liu H, Deng H, De D, Krogstad FM, Krogstad DJ 2011. 4-aminoquinolines active against chloroquine-resistant Plasmodium falciparum: basis of antiparasite activity and quantitative structure-activity relationship analyses. Antimicrob Agents Chemother 55: 2233-2244.

Isaacs AT, Li F, Jasinskiene N, Chen X, Nirmala X, Marinotti O, Vinetz JM, James AJ 2011. Engineered resistance to Plasmodium falciparum development in transgenic Anopheles stephensi. PLoS Pathog 7: e1002017.

Izumiyama S, Omura M, Takasaki T, Ohmae H, Asahi H 2009. Plasmodium falciparum: development and validation of a measure of intraerythrocyic growth using SYBR Green I in a flow cytometer. Exp Parasitol 121: 144-150.

Jacobsson M, Gäredal M, Schultz J, Karlén A 2008. Identification of Plasmodium falciparum spermidine synthase active site binders through structure-based virtual screening. J Med Chem 51: $2777-2786$.

James AA, Beerntsen BT, Capurro M de L, Coates CJ, Coleman J, Jasinskiene N, Krettli AU 1999. Controlling malaria transmission with genetically-engineered, Plasmodium-resistant mosquitoes: milestones in a model system. Parassitologia 41: 461-471.

Jiménez-Díaz MB, Mulet T, Gómez V, Viera S, Alvarez A, Garuti H, Vásquez Y, Fernández A, Ibáñez J, Jiménez M, Gargallo-Viola D, Ângulo-Barturen I 2009. Quantitative measurement of Plasmodium-infected erythrocytes in murine models of malaria by flow cytometry using bidimensional assessment of SYTO-16 fluorescence. Cytometry A 75: 225-235.

Karunamoorthi K 2011. Vector control: a cornerstone in the malaria elimination campaign. Clin Microbiol Infec 17: 1608-1616.

Keenan SM, Geyer JA, Welsh WJ, Prigge ST, Waters NC 2005. Rational inhibitor design and iterative screening in the identification of selective plasmodial cyclin dependent kinase inhibitors. Comb Chem High T Scr 8: 27-38.

Kelly JX, Smilkstein MJ, Brun R, Wittlin S, Cooper RA, Lane KD, Janowsky A, Johnson RA, Dodean RA, Winter R, Hinrichs DJ, Riscoe MK 2009. Discovery of dual function acridones as a new antimalarial chemotype. Nature 459: 270-273.

Kortagere S, Welsh WJ, Morrisey JM, Daly T, Ejigiri I, Sinnis P, Vaidya AB, Bergman LW 2010. Structure-based design of novel small-molecule inhibitors of Plasmodium falciparum. J Chem Inf Model 50: 840-849.

Kouni MH 2003. Potential chemotherapeutic targets in the purine metabolism of parasites. Pharmacol Ther 99: 283-309.

Kouznetsov VV, Gómez-Barrio A 2009. Recent developments in the design and synthesis of hybrid molecules based on aminoquinoline ring and their antiplasmodial evaluation. Eur J Med Chem 44: 3091-3113.

Krettli AU 2009. Antimalarial drug discovery: screening of Brazilian medicinal plants and purified compounds. Exp Opin Drug Disc 4: 95-108.

Krettli AU, Adebayo JO, Krettli LG 2009. Testing of natural products and synthetic molecules aiming at new antimalarials. Curr Drug Targ 10: 261-270.

Krettli AU, Andrade-Neto VF, Brandão MG, Ferrari WM 2001. The search for new antimalarial drugs from plants used to treat fever and malaria or plants randomly selected: a Review. Mem Inst $O_{s-}$ waldo Cruz 96: 1033-1042.

Krudsood S, Wilairatana P, Tangpukdee N, Chalermrut K, Srivilairit S, Thanachartwet V, Muangnoicharoen S, Luplertlop N, Brittenham GM, Looareesuwan S 2006. Safety and tolerability of elubaquine (bulaquine, CDRI 80/53) for treatment of Plasmodium vivax malaria. Thailand Korean J Parasitol 44: 221-228.

Lell B, Kremsner PG 2002. Clindamycin as an antimalarial drug: review of clinical trials. Antimicrob Agents Chemother 46: 2315-2320.

Lucumi E, Darling C, Jo H, Napper AD, Chandramohanadas R, Fisher N, Shone AE, Jing H, Ward SA, Biagini GA, DeGrado WF, Diamond SL, Greenbaum DC 2010. Discovery of potent smallmolecule inhibitors of multidrug-resistant Plasmodium falciparum using a novel miniaturized high-throughput luciferase-based assay. Antimicrob Agents Chemother 54: 3597-3604.

Luzhkov VB, Selisko B, Nordqvist A, Peyrane F, Decroly E, Alvarez K, Karlen A, Canard B, Qvist J 2007. Virtual screening and bio- 
assay study of novel inhibitors for dengue virus mrna cap (nucleoside-2'o)-methyltransferase. Bioorg Med Chem 15: 7795-7802.

Mazier D, Rénia L, Snounou G 2009. A pre-emptive strike against malaria's stealthy hepatic forms. Nat Rev Drug Discov 8: 854-864.

McCarthy JS, Marjason J, Elliott S, Fahey P, Bang G, Malkin E, Tierney E, Aked-Hurditch H, Adda C, Cross N, Richards JS, Fowkes FJI, Boyle MJ, Long C, Druilhe P, Beeson JG, Anders RF 2011. A Phase 1 trial of MSP2-C1, a blood-stage malaria vaccine containing 2 isoforms of MSP2 formulated with MontanideH ISA 720. PLOS ONE 6: e24413.

McKerrow JH, Sun E, Rosenthal PJ, Bouvier J 1993. The proteases and pathogenicity of parasitic protozoa. Annu Rev Microbiol 47: 821-853.

Meister S, Plouffe DM, Kuhen KL, Bonamy GM, Wu T, Barnes SW, Bopp SE, Borboa R, Bright AT, Che J, Cohen S, Dharia NV, Gagaring $\mathrm{K}$, Gettayacamin $\mathrm{M}$, Gordon P, Groessl T, Kato N, Lee MC, McNamara CW, Fidock DA, Nagle A, Nam TG, Richmond W, Roland J, Rottmann M, Zhou B, Froissard P, Glynne RJ, Mazier D, Sattabongkot J, Schultz PG, Tuntland T, Walker JR, Zhou Y, Chatterjee A, Diagana TT, Winzeler EA 2011. Imaging of Plasmodium liver stages to drive next-generation antimalarial drug discovery. Science 334: 1372-1377.

Menan H, Faye O, Same-Ekobo A, Oga AS, Faye B, Kiki Barro CP, Kuete T, N'diaye JL, Vicky AM, Tine R, Yavo W, Kane D, Kassi KF, Kone M 2011. Comparative study of the efficacy and tolerability of dihydroartemisinin-piperaquine-trimethoprim versus artemether-lumefantrine in the treatment of uncomplicated Plasmodium falciparum malaria in Cameroon, Ivory Coast and Senegal. Malar J 10: 185.

Morris GM, Goodsell DS, Halliday RS, Huey R, Hart WE, Belew RK, Olson AJ 1998. Automated docking using a lamarckian genetic algorithm and empirical binding free energy function. J Comp Chem 19: 1639-1662.

Mout R, Xu ZD, Wolf AK, Davisson VJ, Jarori GK 2012. Anti-malarial activity of geldanamycin derivatives in mice infected with Plasmodium yoelii. Malar J 11: 54.

Mugnaini C, Rajamaki S, Tintori C, Corelli F, Massa S, Witvrouw M, Debyser Z, Veljkovic V, Botta M 2007. Toward novel HIV-1 integrase binding inhibitors: molecular modeling, synthesis, and biological studies. Bioorg Med Chem Lett 17: 5370-5373.

Murata CE, Goldberg DE 2003. Plasmodium falciparum falcilysin: a metalloprotease with dual specificity. J Biol Chem 278: 3802238028.

Muregi FW, Wamakima HN, Kimani FT 2012. Novel drug targets in malaria parasite with potential to yield antimalarial drugs with long useful therapeutic lives. Curr Pharm Des 18: 3505-3521.

Ncokazi KK, Egan TJ 2005. A colorimetric high-throughput betahematin inhibition screening assay for use in the search for antimalarial compounds. Anal Biochem 338: 306-319.

Neuenfeldt PD, Drawanz BB, Aguiar ACC, Figueiredo F, Krettli AU, Cunico W 2011. Multicomponent synthesis of new primaquine thiazolidinone derivatives. Synthesis 23: 3866-3870.

Newman DJ, Cragg GMJ 2007. Natural products as sources of new drugs over the last 25 years. Nat Prod 70: 461-477.

Nicola G, Smith CA, Lucumi E, Kuo MR, Karagyozov L, Fidock DA, Sacchettini JC, Abagyan R 2007. Discovery of novel inhibitors targeting enoyl-acyl carrier protein reductase in Plasmodium falciparum by structure-based virtual screening. Biochem Biophys Res Commun 358: 686-691.

Noedl H, Wongsrichanalai C, Miller RS, Myint KS, Looareesuwan S, Sukthana Y, Wongchotigul V, Kollaritsch H, Wiedermann G,
Wernsdorfer WH 2002. Plasmodium falciparum: effect of antimalarial drugs on the production and secretion characteristics of histidine-rich protein II. Exp Parasitol 102: 157-163.

Nsanzabana C, Rosenthal PJ 2011. In vitro activity of antiretroviral drugs against Plasmodium falciparum. Antimicrob Agents Chemother 55: 5073-5077.

Obonyo CO, Juma EA 2012. Clindamycin plus quinine for treating uncomplicated falciparum malaria: a systematic review and meta-analysis. Malar J 11: 2.

O'Neill PM, Amewu RK, Nixon GL, Bousejra ElGarah F, Mungthin M, Chadwick J, Shone AE, Vivas L, Lander H, Barton V, Muangnoicharoen S, Bray PG, Davies J, Park BK, Wittlin S, Brun R, Preschel M, Zhang K, Ward SA 2010. Identification of a 1,2,4,5tetraoxane antimalarial drug-development candidate (RKA182) with superior properties to the semisynthetic artemisinins. Angew Chem 122: 5829-5833.

Parapini S, Basilico N, Pasini E, Egan TJ, Olliaro P, Taramelli D, Monti D 2000. Standardization of the physicochemical parameters to assess in vitro the beta-hematin inhibitory activity of antimalarial drugs. Exp Parasitol 96: 249-256.

Parikh S, Liu J, Sijwali P, Gut J, Goldbert DE, Rosenthal PJ 2006. Antimalarial effects of human immunodeficiency virus type 1 protease inhibitors differ from those of the aspartic protease inhibitor pepstatin. Antimicrob Agents Chemother 50: 2207-2209.

Peatey CL, Andrews KT, Eickel N, MacDonald T, Butterworth AS, Trenholme KR, Gardiner DL, McCarthy JS, Skinner-Adams TS 2010. Antimalarial asexual stage-specific and gametocytocidal activities of HIV protease inhibitors. Antimicrob Agents Chemother 54: 1334-1337.

Peatey CL, Leroy D, Gardiner DL, Trenholme KR 2012. Anti-malarial drugs: how effective are they against Plasmodium falciparum gametocytes? Malar J 11: 34.

Penna-Coutinho J, Cortopassi WA, Oliveira AA, França TC, Krettli AU 2011. Antimalarial activity of potential inhibitors of Plasmodium falciparum lactate dehydrogenase enzyme selected by docking studies. PLOS ONE 6: 21237.

Perkins DJ, Were T, Davenport GC, Kempaiah P, Hittner JB, Ong'echa MJ 2011. Severe malarial anemia: innate immunity and pathogenesis. Int J Biol Sci 7: 1427-1442.

Peters W 1965. Drug resistance in Plasmodium berghei Vincke and Lips, 1948. I. Chloroquine resistance. Exp Parasitol 17: 80-89.

Price RN, Douglas NM, Anstey NM 2009. New developments in Plasmodium vivax malaria. Severe disease and the rise of chloroquine resistance. Curr Opin Infect Dis 22: 430-435.

Quashie NB, de Koning HP, Ranford-Cartwright LC 2006. An improved and highly sensitive microfluorimetric method for assessing susceptibility of Plasmodium falciparum to antimalarial drugs in vitro. Malar J 5: 95-100.

Ridley RG 2002. Medical need, scientific opportunity and the drive for antimalarial drugs. Nat 415: 686-693.

Rodrigues FG, Santos MN, de Carvalho TXT, Rocha BC, Riehle MA, Pimenta PFP, Abraham EG, Jacobs-Lorena M, Alves de Brito CG, Moreira LA 2008. Expression of a mutated phospholipase A2 in transgenic Aedes fluviatilis mosquitoes impacts Plasmodium gallinaceum development. Insect Mol Biol 17: 175-183.

Rottmann M, McNamara C, Yeung BK, Lee MC, Zou B, Russell B, Seitz P, Plouffe DM, Dharia NV, Tan J, Cohen SB, Spencer KR, González-Páez GE, Lakshminarayana SB, Goh A, Suwanarusk R, Jegla T, Schmitt EK, Beck HP, Brun R, Nosten F, Renia L, Dartois V, Keller TH, Fidock DA, Winzeler EA, Diagana TT 2010. Spiroindolones, a potent compound class for the treatment of malaria. Science 329: 1175-1180. 
Roy A, D’Annessa I, Nielsen CJ, Tordrup D, Laursen RR, Knudsen BR, Desideri A, Andersen FF 2011. Peptide inhibition of topoisomerase IB from Plasmodium falciparum. Mol Biol Int: 854626.

Sá MS, de Menezes MN, Krettli AU, Ribeiro IM, Tomassini TC, Ribeiro dos Santos R, de Azevedo Jr WF, Soares MB 2011. Antimalarial activity of physalins B, D, F, and G. $J$ Nat Prod 74: 2269-2272.

Sanchez BA, Mota MM, Sultan AA, Carvalho LH 2004. Plasmodium berghei parasite transformed with green fluorescent protein for screening blood schizontocidal agents. Int $J$ Parasitol 34: 485-490.

Sanchez BA, Varotti FP, Rodrigues FG, Carvalho LH 2007. Validation of a Plasmodium falciparum parasite transformed with green fluorescent protein for antimalarial drug screening. J Microbiol Methods 69: 518-522.

Schofield L, Grau GE 2005. Immunological processes in malaria pathogenesis. Nat Rev Immunol 5: 722-735.

Schwartz L, Brown GV, Genton B, Moorthy VS 2012. A review of malaria vaccine clinical projects based on the WHO rainbow table. Malar J 11: 11.

Shah F, Mukherjee P, Gut J, Legac J, Rosenthal PJ, Tekwani BL, Avery MA 2011. Identification of novel malarial cysteine protease inhibitors using structure-based virtual screening of a focused cysteine protease inhibitor library. J Chem Inf Mod 51: 852-864.

Sidhu AB, Sun Q, Nkrumah LJ, Dunne MW, Sacchettini JC, Fidock DA 2007. In vitro efficacy, resistance selection and structural modeling studies implicate the malarial parasite apicoplast as the target of azithromycin. J Biol Chem 282: 2494-2504.

Smilkstein M, Sriwilaijaroen N, Kelly JX, Wilairat P, Riscoe M 2004. Simple and inexpensive fluorescence-based technique for high-throughput antimalarial drug screening. Antimicrob Agents Chemother 48: 1803-1806.

Somsak V, Srichairatanakool S, Yuthavong Y, Kamchonwongpaisan S, Uthaipibull C 2012. Flow cytometric enumeration of Plasmodium berghei-infected red blood cells stained with SYBR Green I. Acta Trop 122: 113-118.

Stocks PA, Raynes KJ, Bray PG, Park BK, O’Neill PM, Ward SA 2002. Novel short chain chloroquine analogues retain activity against chloroquine resistant k1 Plasmodium falciparum. J Med Chem 45: 4975-4983.

Sturm A, Amino R, van de Sand C, Regen T, Retzlaff S, Rennenberg A, Krueger A, Pollok JM, Menard R, Heussler VT 2006. Manipulation of host hepatocytes by the malaria parasite for delivery into liver sinusoids. Science 313: 1287-1290.

Townell N, Looke D, McDougall D, McCarthy JS 2012. Relapse of imported Plasmodium vivax malaria is related to primaquine dose: a retrospective study. Malar J 11: 214.

Tshefu AK, Gaye O, Kayentao K, Thompson R, Bhatt KM, Sesay SS, Bustos DG, Tjitra E, Bedu-Addo G, Borghini-Fuhrer I, Duparc S, Shin CS, Fleckenstein L, Pyronaridine-artesunate Study Team
2010. Efficacy and safety of a fixed-dose oral combination of pyronaridine-artesunate compared with artemether-lumefantrine in children and adults with uncomplicated Plasmodium falciparum malaria: a randomised non-inferiority trial. Lancet 375: 1457-1467.

Uchôa VT, de Paula RC, Krettli LG, Santana AEG, Krettli AU 2010. Antimalarial activity of compounds and mixed fractions of $\mathrm{Ce}$ cropia pachystachya. Drug Dev Res 91: 82-91.

Valecha N, Adak T, Bagga AK, Asthana OP, Srivastava J S, Joshi $\mathrm{H}$, Sharma VP 2001. Comparative antirelapse efficacy of CDRI compound 80/53 (bulaquine) vs. primaquine in double blind clinical trial. Curr Sci India 80: 25.

Warhurst DC, Craig JC, Adagu IS, Guy RK, Madrid PB, Fivelman QL 2007. Activity of piperaquine and other 4-aminoquinoline antiplasmodial drugs against chloroquine-sensitive and resistant blood-stages of Plasmodium falciparum. Role of betahaematin inhibition and drug concentration in vacuolar water and lipidphases. Biochem Pharm 73: 1910-1926.

Wells TN, Burrows JN, Baird JK 2010. Targeting the hypnozoite reservoir of Plasmodium vivax: the hidden obstacle to malaria elimination. Trends Parasitol 26: 145-151.

WHO 2010a. Guidelines for the treatment of malaria, 2nd ed., WHO, Geneve, 194 pp.

WHO 2010b. Global report on antimalarial drug efficacy and drug resistance: 2000-2010, WHO, Geneve, 121 pp.

WHO 2011. World Malaria Report 2011, WHO, Geneve, 3 pp.

Wiesner J, Borrmann S, Jomaa H 2003. Fosmidomycin for the treatment of malaria. Parasitol Res 90 (Suppl. 2): S71-S76.

Wiesner J, Henschker D, Hutchinson DB, Beck E, Jomaa H 2002. In vitro and in vivo synergy of fosmidomycin, a novel antimalarial drug, with clindamycin. Antimicrob Agents Chemother 46: 2889-2894.

Willcox M 2011. Improved traditional phytomedicines in current use for the clinical treatment of malaria. Planta Med 77: 662-671.

Williams JL 1999. Stimulation of Plasmodium falciparum gametocytogenesis by conditioned medium from parasite cultures. Am J Trop Med Hyg 60: 7-13.

Wilson DW, Crabb BS, Beeson JG 2010. Development of fluorescent Plasmodium falciparum for in vitro growth inhibition assays. Malar J 3: 152.

Wright AD, Lang-Unnasch N 2005. Potential antimalarial lead structures from fungi of marine origin. Planta Med 71: 964-966.

Wu T, Nagle A, Kuhen K, Gagaring K, Borboa R, Francek C, Chen Z, Plouffe D, Goh A, Lakshminarayana SB, Wu J, Ang HQ, Zeng P, Kang ML, Tan W, Tan M, Ye N, Lin X, Caldwell C, Ek J, Skolnik S, Liu F, Wang J, Chang J, Li C, Hollenbeck T, Tuntland T, Isbell J, Fischli C, Brun R, Rottmann M, Dartois V, Keller T, Diagana T, Winzeler E, Glynne R, Tully DC, Chatterjee AK 2011. Imidazolopiperazines: hit to lead optimization of new antimalarial agents. JMed Chem 54: 5116-5130. 


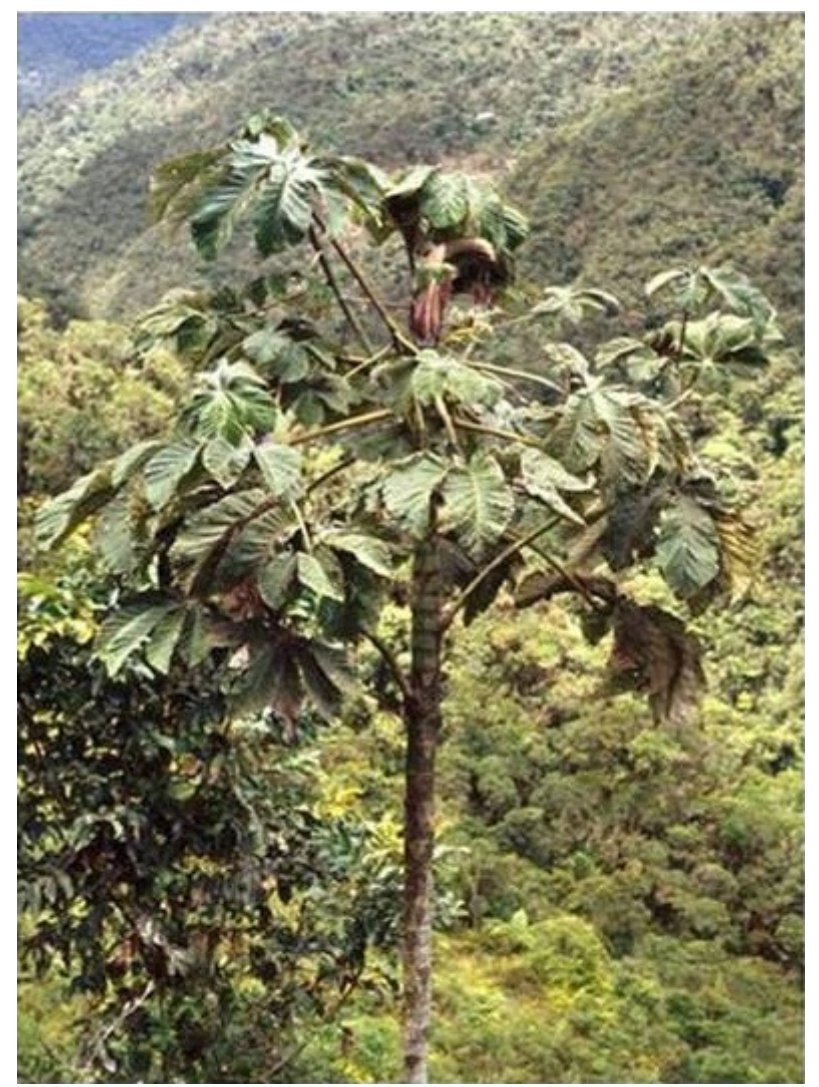

Cecropia sp., a medicinal plant popularly known as imbaúba or embaúba, is used against human malaria in endemic areas of the Amazon and in other regions of Latin America. A strong activity against malaria parasites have been demonstrated. 